\title{
Processes that influence carbon isotope variations in salt marsh sediments
}

\author{
L. M. Ember, D. F. Williams \& J. T. Morris \\ Marine Science Program and Belle W. Baruch Institute for Marine Biology and Coastal Research, \\ University of South Carolina, Columbia, South Carolina 29208, USA
}

\begin{abstract}
Salt marsh sedimentary organic matter (SOM) is a mixture of organic carbon from several sources difficult to identify quantitatively. Geochemical analyses of sediment cores at 4 sites in salt marshes at North Inlet, South Carolina (USA), dominated by Spartina alterniflora, were used to investigate accumulation and diagenesis of organic matter in sediments. Stable carbon isotope ratios $\left({ }^{13} \mathrm{C}\right)$ and concentrations of organic carbon in the fine fraction of SOM ranged from -22 to $-17 \%$ and 2 to $9 \%$, respectively. $\delta^{13} \mathrm{C}$ values were significantly more positive in sediments from a short-form Spartina zone than from intermediate or tall-form Spartina areas. Samples from the site dominated by short-form $S$. alterniflora also contained significantly higher amounts of organic carbon than sites closer to the tidal creek, and demonstrated a positive correlation between organic carbon content and isotopically more positive $\delta^{13} \mathrm{C}$ values. Spartina litter buried for $1.25 \mathrm{yr}$ and Spartina lignin had $\delta^{13} \mathrm{C}$ values of -15.35 and $-16.34 \%$ respectively and were significantly more depleted in ${ }^{13} \mathrm{C}$ than fresh $S$. alterniflora $(-13.63 \%)$, but not as depleted as the fine fraction of SOM. However, litter harvested from the marsh surface after 1.25 yr of decomposition had a $\delta^{13} \mathrm{C}$ value of $-13.75 \%$. The $\delta^{13} \mathrm{C}$ values of SOM appear to be influenced by a combination of processes, including the selective preservation of isotopically light refractory carbon, aerobic and anaerobic decay processes, sedimentation of allochthonous carbon from plankton or terrestrial sources, and bioturbation.
\end{abstract}

\section{INTRODUCTION}

Spartina alterniflora Loisel. is the major primary producer in salt marshes of the eastern coast of the United States (Howarth \& Teal 1979, Marinucci 1982). Most of the $S$. alterniflora production apparently decomposes quickly within the salt marsh system (Kruczynski et al. 1978, White et al. 1978, Haines \& Hanson 1979). In Massachusetts, ca $90 \%$ of net primary production is oxidized (Howarth \& Teal 1979, Howarth \& Giblin 1983). Recent data suggest that only a small fraction of primary production is either preserved in salt marsh sediment or exported as particulate and dissolved organic matter (Haines 1977, Peterson et al. 1980).

Whether benthic diatoms and algae, bacteria, and estuarine phytoplankton are significant contributors to salt marsh sedimentary organic matter (SOM) - even in salt marshes where Spartina alterniflora is the dominant plant species - is an important ecological question (Fry et al. 1977, Haines 1977, Hackney \& Haines 1980, Hughes \& Sherr 1983). Studies to characterize the proportion of each of these sources retained in
SOM have used various analytical chemical techniques, especially isotope ratio mass spectrometry. In some systems, stable carbon isotope ratios $\left({ }^{13} \mathrm{C} /{ }^{12} \mathrm{C}\right)$ can be used as an 'isotopic fingerprint' to identify the sources of organic materials (Fry \& Sherr 1984) because biological reaction pathways generally favor the lighter carbon isotope $\left({ }^{12} \mathrm{C}\right)$. Photosynthesis, for example, proceeds along different pathways, which lead to products with characteristic ranges of $\delta^{13} \mathrm{C}$ values (Table 1) (Park \& Epstein 1960, 1961, Bender 1971, Smith \& Epstein 1971). Because the ranges of the $\delta^{13} \mathrm{C}$ values often overlap and the quantities of material contributed can vary, stable carbon isotope analysis alone cannot unequivocally determine the contribution of each plant source. For example, bacteria and phytoplankton have similar ranges in $\delta^{13} \mathrm{C}$ values, and the problem becomes more complicated if other possible sources of salt marsh SOM, such as C-3 plants like Juncus are considered (Table 1). A stable carbon isotope analysis of salt marsh SOM must consider all these materials as possible contributors to the $\delta^{13} \mathrm{C}$ signature of the SOM.

Aside from the sources of organic matter, stable 
Table 1. Sources of organic carbon found in salt marsh sediment

\begin{tabular}{|c|c|c|c|}
\hline Source & Location & $\delta^{13} \mathrm{C}$ & Reference \\
\hline \multirow[t]{8}{*}{ Spartina } & Mississippi & $\begin{array}{l}-12.4 \\
-13.6\end{array}$ & $\begin{array}{l}\text { Hackney \& Haines (1980) } \\
\text { Thayer (1978) }\end{array}$ \\
\hline & South Carolina & & \\
\hline & Spartina tall form & -13.5 & This study \\
\hline & Spartina short form & -13.7 & This study \\
\hline & Georgia & & \\
\hline & Spartina tall form & -13.6 & Haines (1976) \\
\hline & Spartina short form & -12.7 & Haines (1976) \\
\hline & $\begin{array}{l}\text { Bay of Fundy } \\
\text { Florida }\end{array}$ & $\begin{array}{l}-13.1 \\
-12.5\end{array}$ & $\begin{array}{l}\text { Schwinghamer et al. (1983) } \\
\text { Johnson \& Calder (1973) }\end{array}$ \\
\hline \multirow[t]{3}{*}{ Juncus } & Mississippi & -26.2 & Hackney \& Haines (1980) \\
\hline & Georgia & -25.8 & Hughes \& Sherr (1983) \\
\hline & Florida & -23.2 & Johnson \& Calder (1973) \\
\hline \multirow[t]{2}{*}{ Benthic algae } & Florida & -12 to -18 & Fry (1984) \\
\hline & Lab culture & -20.4 & De Niro \& Epstein (1978) \\
\hline \multirow[t]{3}{*}{ Benthic diatoms } & Georgia & -16.2 to -17.9 & Haines (1976) \\
\hline & Malaysia & -17.8 & Rodelli et al. (1984) \\
\hline & Bay of Fundy & $-13.6,-18.1$ & Schwinghamer et al. (1983) \\
\hline \multirow[t]{6}{*}{ Phytoplankton } & New Zealand & -18.6 & Stephenson \& Lyon (1982) \\
\hline & Rhode Island & -21.3 & Gearing et a. (1984) \\
\hline & Malaysia & -21.0 & Rodelli et al. (1984) \\
\hline & Georgia & -20.0 to -22.7 & Haines \& Montague (1979) \\
\hline & Bay of Fundy & -19.2 & Schwinghamer et al. (1983) \\
\hline & Peru & -20.0 & Degens et al. (1968) \\
\hline \multirow[t]{3}{*}{ Bacteria } & Lab culture & $-20.5,-22.5$ & Sirevag et al. (1977) \\
\hline & Estuary & -21.0 & Spies \& DesMarias (1983) \\
\hline & Lab culture & -24.4 & DeNiro \& Epstein (1978) \\
\hline
\end{tabular}

carbon isotope values of SOM vary also due to factors such as diagenesis, bioturbation and differential rates of accumulation and decomposition in the salt marsh. This information has not been integrated systematically to examine the patterns of salt marsh detrital decomposition. Due to the limitations of carbon isotope ratio analysis alone, determination of total organic carbon content and total organic nitrogen may also be useful for differentiating sources of SOM. In this paper we investigate the variations in $\delta^{13} \mathrm{C}$ values and carbon and nitrogen concentrations with sediment depth at several locations within the marsh.

\section{MATERIALS AND METHODS}

Sediment cores were taken seasonally at 4 sites in salt marshes of the Belle $W$. Baruch Institute at Georgetown, South Carolina (USA) (Fig. 1). The sites are representative of 4 distinct floral zones: Creek bank (CB), tall Spartina alterniflora marsh (TS), and medium S. alterniflora (MS) at Bread and Butter Creek, and short $S$. alterniflora (SS) at Goat Island (Fig. 1). Every site was cored to a depth of $40 \mathrm{~cm}$ during August and November 1983, and February and April 1984.
Cores were split lengthwise in the field and sectioned at $5 \mathrm{~cm}$ intervals. A $2 \mathrm{~cm}$ thick sample was removed from each section, frozen immediately on dry ice in the field, and transported to the laboratory for processing (Ember 1985). Prior to analysis, sediment samples were thawed and living root and rhizome material was carefully removed. Carbonate contamination, which could shift isotopic values in the positive direction, was avoided by treating the samples with dilute hydrochloric acid for at least $12 \mathrm{~h}$. Treated sediment was washed, centrifuged to remove excess water, dried, and ground to a fine powder with mortar and pestle.

In preparation for mass spectrometric analysis, each dried, powdered sediment sample was mixed with cupric oxide and silver metal powder in a brass envelope. The envelope was placed in a quartz ampule, which was evacuated and flame sealed, based on modifications to the procedure described by Buchanan \& Corcoran (1959). Ampules were combusted at $900^{\circ} \mathrm{C}$ for $3 \mathrm{~h}$ and allowed to cool. The resultant carbon dioxide was purified of contaminants by cryogenic removal of nitrogen and water and by passage over copper wool heated to $250^{\circ} \mathrm{C}$, which reduces the oxides of nitrogen and sulfur into nitrogen gas and elemental sulfur, respectively. 


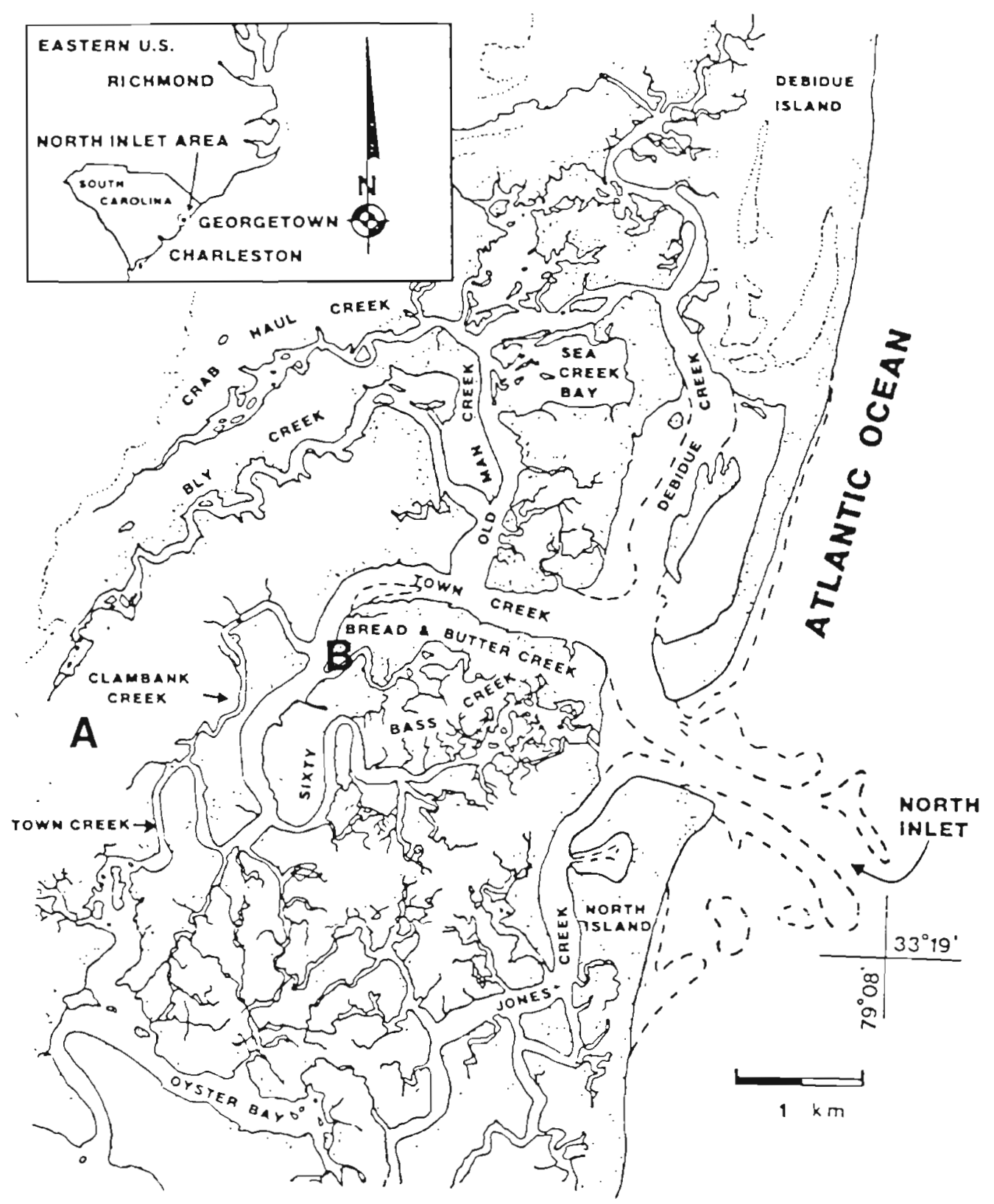

Fig. 1. North Inlet salt marsh of the Belle W. Baruch Institute for Marine Biology and Coastal Research showing the locations of sites where sediment cores were taken. A: short Spartina alterniflora site (SS) Goat Island site; B: Bread and Butter Creek sites: tidal creek bank (CB), tall Spartina zone (TS), and medium Spartina (MS) zone. Nomenclature consistent with sites studied by other investigators (Gardner et al. in press, Sharma et al. in press). Sites CB, TS, MS, and SS are equivalent to sites BB1, BB2, BB4 and GI4 respectively

Gas samples were analysed on a Micromass VG602D isotope ratio mass spectrometer. The $\delta^{13} \mathrm{C}$ values are corrected for ${ }^{17} \mathrm{O}$ contribution according to the procedure of Craig (1957) and reported in per mil (\%) relative to the PDB standard. The average analytical precision was $0.14 \pm 0.09(\%)$ based on 19 sets of replicate samples. NBS-21, a graphite standard, was combusted with each group of samples. Mean and standard deviation for 14 replicates of NBS-21 were $-28.29 \pm 0.10 \%$ relative to PDB. The published value for NBS-21 relative to PDB is $-28.13 \pm 0.03 \%(n=3)$ (Coplen et al. 1983).

A portion of each dried sediment sample was also analyzed for total carbon and nitrogen content using a Hewlett Packard model 185 CHN Analyzer. Duplicate samples were analyzed and compared to a standard curve generated by the combustion of known quantities of acetanilide standard. 
For the decomposition experiment, senescent Spartina alterniflora stems and leaves were collected during autumn 1983, sealed inside $2 \mathrm{~mm}$-mesh fiberglass litter bags, and placed on the surface or buried at a depth of $5 \mathrm{~cm}$ in the marsh. Our methods followed those of Morris \& Lajtha (1986). Litter harvested after 15 mo of decomposition was analysed for carbon isotopes and carbon and nitrogen concentration as described above. After removal from the marsh, the material was washed to remove the encrusting mud, dried at $70^{\circ} \mathrm{C}$, and ground in a Wiley Mill in preparation for $\delta^{13} \mathrm{C}$ determination. Samples of lignin from a chemical digest of fresh $S$. alterniflora litter were provided by Jerry Melillo of the Marine Biological Laboratory, Woods Hole. The lignin extractions were based on the acid detergent procedure of Georing \& Van Soest (1970).

\section{RESULTS}

The relation between carbon content and $\delta^{13} \mathrm{C}$ values of sediment samples is shown in Fig. 2. The $\delta^{13} \mathrm{C}$ of all SOM samples collected from the surface and to a maximum depth of $35 \mathrm{~cm}(-22$ to $-17 \%)$ are consistently 4 to $9 \%$ more negative than the $\delta^{13} \mathrm{C}$ of the major macrophyte present, Spartina alterniflora $\left(-13.5 \%\right.$ ) (Fig. 2). Mean SOM $\delta^{13} \mathrm{C}$ values, averaged over all depths, are more positive with increasing distance from the marsh creek; they increase from -21.00 at the creekbank (CB) to $-18.43 \%$ at the short $S$. alterniflora zone (SS) (Table 2)

There was also a significant relation between more positive $\delta^{13} \mathrm{C}$ values and the increasing organic content in sediments at sites further from the creekbank (Fig. 3). The majority of the samples with $\delta^{13} \mathrm{C}$ values

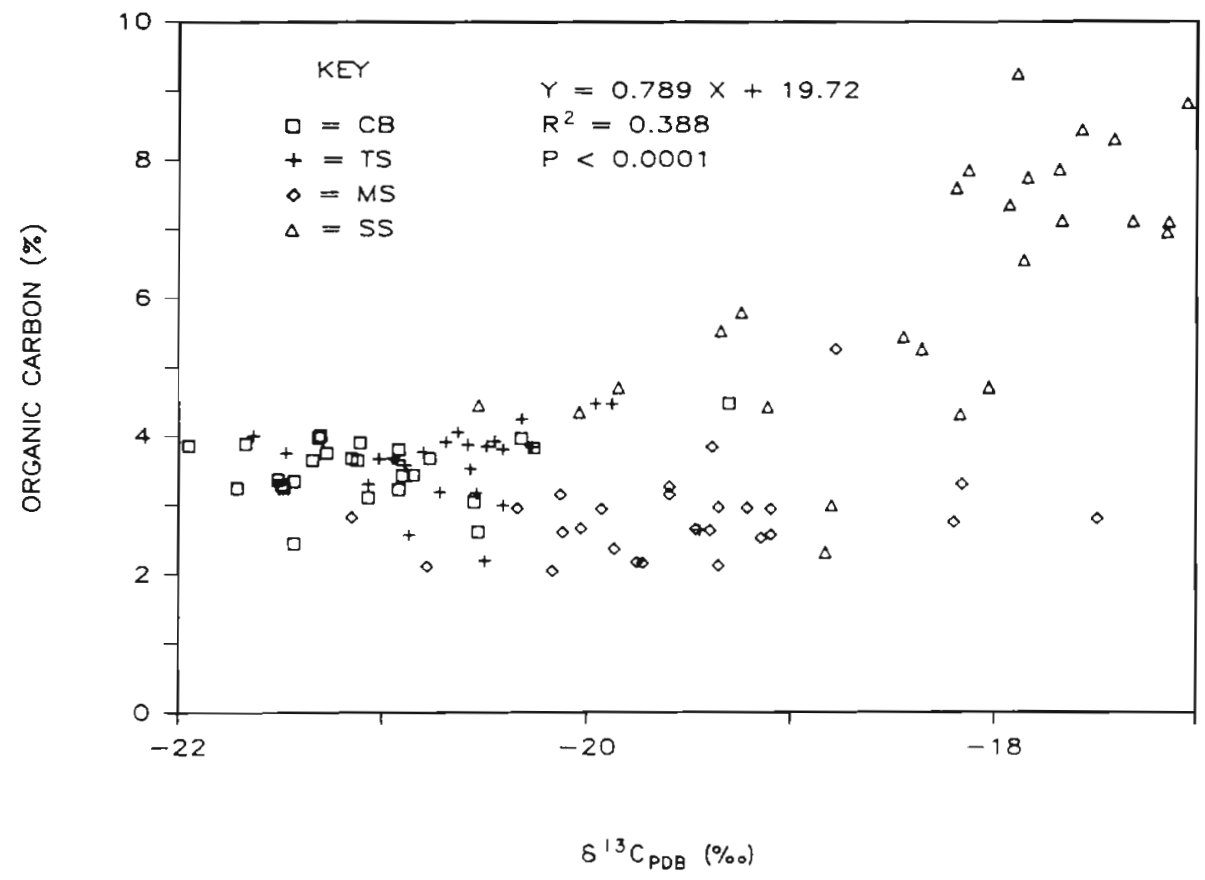

Fig. 2. Plot of percent organic carbon (Wt/Wt) vs $\delta^{13} \mathrm{C}(\%)$ for samples analyzed at all depths at each site $(\mathrm{n}=103)$. Sampling sites: CB: tidal creek bank, TS: tall Spartina, MS: medium Spartina, SS: short Spartina

Table 2. $\delta^{13} \mathrm{C}$ and organic carbon content (\% C of dry sediment wt) of marsh sediments (SOM), sorted by location over all depths $(0$ to $35 \mathrm{~cm})$ and seasons

\begin{tabular}{|c|c|c|c|c|c|c|c|c|c|}
\hline \multirow{2}{*}{$\begin{array}{l}\text { Marsh } \\
\text { site } \\
\mathrm{CB}\end{array}$} & \multirow{2}{*}{$\begin{array}{c}\begin{array}{c}\text { Growth } \\
\text { form }\end{array} \\
\text { Creek Bank }\end{array}$} & \multirow{2}{*}{$\begin{array}{l}\mathrm{N} \\
28\end{array}$} & \multicolumn{2}{|c|}{$\underset{(\%)}{\delta^{13} \mathrm{C} \pm \mathrm{SD}}$} & \multirow{2}{*}{$\frac{\text { Sig. }}{A}$} & \multicolumn{2}{|c|}{$\begin{array}{c}\mathrm{SOM} \pm \mathrm{SD} \\
(\% \mathrm{C})\end{array}$} & \multicolumn{2}{|c|}{ Sig. } \\
\hline & & & -21.15 & 0.50 & & 3.54 & 0.45 & A & B \\
\hline TS & Tall Spartina & 33 & -20.55 & 0.59 & $B$ & 3.61 & 0.56 & A & \\
\hline MS & Medium Spartina & 29 & -19.43 & 0.84 & C & 2.84 & 0.65 & & B \\
\hline SS & Short Spartina & 31 & -18.43 & 1.03 & $\mathrm{D}$ & 6.24 & 1.84 & $\mathrm{C}$ & \\
\hline
\end{tabular}




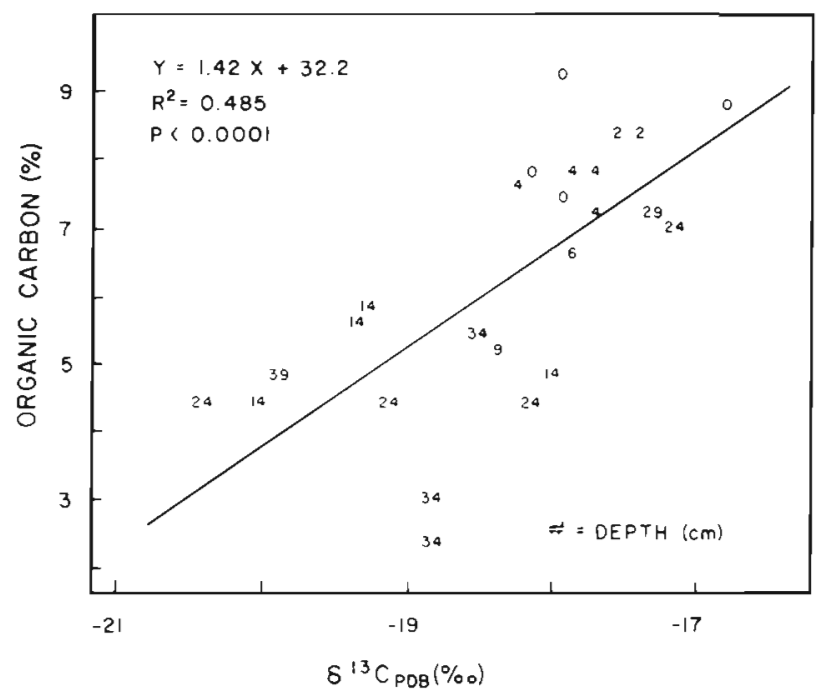

Fig. 3. Organic carbon content and stable carbon isotope values as a function of depth in samples collected at the short Spartina site (SS) at 4 seasonal intervals. Numbers: depth in $\mathrm{cm}$ below surface; line: least squares fit to data

more negative than -20.2 were collected at $\mathrm{CB}$ and the tall Spartina alterniflora zone (TS). Samples taken between the surface and a depth of $35 \mathrm{~cm}$ from these 2 sites as well as the medium $S$. alterniflora site (MS) had mean organic carbon content values of 2.84 to $3.61 \%$, while the SOM at SS had significantly higher organic carbon contents $(p<0.05)$ with a mean of $6.24 \%$ (Table 2). Goat Island sediments at SS showed a significant ( $p<0.0001)$ positive correlation between organic carbon content and $\delta^{13} \mathrm{C}$ values (Fig. 3). This site had sediments with greater than $5 \%$ organic carbon content and $\delta^{13} \mathrm{C}$ values more positive than $-19 \%$. If the SS samples are not considered (Fig. 2), the remaining data do not show a correlation between organic carbon and $\delta^{13} \mathrm{C}$ values.

Results of a decomposition study showed that the change in isotopic composition of litter apparently depends on whether the litter is degraded on the marsh surface or subsurface (Table 3). Litter buried at $5 \mathrm{~cm}$ depth for 15 mo became nearly $2 \%$ more negative than fresh litter, whereas 15 mo litter from the marsh surface showed little change in isotopic composition. There was no significant difference in isotopic composition among sites within litter type despite large differences in the extent of decomposition, especially between surface litter from TS and SS sites (Table 3). Furthermore, there was no discernible relation between the degree of decomposition (\% of original weight remaining) and the change in isotopic composition.

Fig. 4 shows the relation between $\mathrm{C} / \mathrm{N}$ ratio and $\delta^{13} \mathrm{C}$ values for sieved sediment samples collected during April from all sites at a depth of 29 to $34 \mathrm{~cm}$. Ca $97 \%$ of live root and rhizome biomass is found above $25 \mathrm{~cm}$ in the North Inlet marsh (Morris \& Whiting 1986); thus, these samples were virtually free of living plant material, including algae, that could have influenced the isotopic composition of the sample. The results are similar to those of Schwinghamer et al. (1983). The fine fraction $(<710 \mu \mathrm{m})$ is nearly $5 \%$ more negative than the macro-organic matter, composed exclusively of dead Spartina alterniflora roots and rhizome material sieved from the cores with repeated washings with distilled water. The dead macro-organic matter is ca $2 \%$ more negative than live $S$. alterniflora. Macroorganic matter also has a higher $\mathrm{C} / \mathrm{N}$ ratio than the fine particulates.

\section{DISCUSSION}

\section{Preservation of plant materials in salt marsh sediments}

The observation that the mean $\delta^{13} \mathrm{C}$ values of salt marsh sediment are more negative than those of Spar-

Table 3. Spartina alterniflora. Comparison of stable carbon isotopic composition of fresh litter, lignin, and degraded litter (15 mo) from litter bags deployed at various sites within the marsh (TS: tall Spartina zone, SS: short Spartina zone, CB: creek bank zone)

\begin{tabular}{|lcccc|}
\hline \multicolumn{1}{|c}{ Material } & Site & $\mathrm{N}$ & $\begin{array}{c}\delta^{13} \mathrm{C} \pm \mathrm{SE} \\
(\%)\end{array}$ & $\begin{array}{c}\text { Remaining } \\
\text { weight }(\%)\end{array}$ \\
\hline Fresh litter & & & $-13.67 \pm 0.09$ \\
& TS & 2 & $-13.76 \pm 0.02$ \\
Degraded litter & SS & 2 & $-13.62 \pm 0.24$ & 26.24 \\
(surface) & TS & 3 & $-13.95 \pm 0.01$ & 4.02 \\
Degraded litter & SS & 2 & $-15.45 \pm 0.16$ & 26.07 \\
(subsurface, $5 \mathrm{~cm}$ ) & TS & 2 & $-15.50 \pm 1.24$ & 42.90 \\
& SS & 2 & $-15.26 \pm 0.04$ & 34.24 \\
Spartina lignin & CB & 2 & $-16.34 \pm 0.27$ & \\
\hline
\end{tabular}


tina alterniflora may suggest that the latter is not the major component of SOM. If carbon compounds within live $S$. alterniflora are uniformly labelled, then the $\delta^{13} \mathrm{C}$ value of SOM should be closer to the $-13.5 \%$ of live $S$. alterniflora if a significant amount of $S$. alterniflora is incorporated into SOM (Johnson \& Calder 1973 , Haines 1976, Hackney \& Haines 1980, Hughes \& Sherr 1983). Alternatively, if the biochemical constituents of $S$. alterniflora have different $\delta^{13} \mathrm{C}$ values, their individual contributions may be measured in the sedimentary record. Although the major macrophyte, S. alterniflora, would seem to be the most available source of sedimentary organic carbon in this ecosystem, macrophyte organic carbon is probably not retained in the sediment in an unaltered state, and is not the exclusive contributor of organic carbon to the sediment. An understanding of how SOM acquires a characteristic $\delta^{13} \mathrm{C}$ value would add to our knowledge of early diagenesis of organic matter in salt marsh soils.

There are several processes that may explain the observed relations between stable carbon isotope values of sediments, their organic contents, and location within the salt marsh. The first process involves the selective preservation of the more refractory biochemical components of Spartina alterniflora over the more labile fractions. About $75 \%$ of $S$. alterniflora is lignocellulose, a structural polysaccharide (Maccubbin \& Hodson 1980, Benner et al. 1984b). Cellulose carbon appears to be heavier isotopically than the whole tissue. For example, cellulose from a wide variety of C4 species ranges in isotopic composition from -11.0 to $-12.7 \%$ (Sternberg et al. 1984) while whole tissue ranges from -18.6 to $-9.3 \%$ (Bender 1971, Smith \& Epstein 1971). As cellulose decays, the $\delta^{13} \mathrm{C}$ of the remaining sediment would become more negative, reflecting the proportional increase of lignin in the SOM. We analysed S. alterniflora lignin that had been extracted from fresh litter and found it to be significantly more depleted in ${ }^{13} \mathrm{C}$ than the fresh litter (Table 3). The process of lignin enrichment during the microbial decomposition of Spartina detritus in salt marsh sediments was observed by Maccubbin \& Hodson (1980), Hodson et al. (1984), and Benner et al. (1984a, b, 1985, 1986). These authors described a model for the selective degradation of the polysaccharide components of Spartina compared to the lignin component under both anaerobic and aerobic conditions.

Hatcher et al. $(1981,1982,1983)$ and Spiker \& Hatcher (1984) presented a similar model concerning the selective preservation of humins and the loss of carbohydrates in a marine algal sapropel. Humins, like lignins, are more depleted in $\delta^{13} \mathrm{C}$ than carbohydrates and are also resistant to microbial decomposition. The selective preservation hypothesis is supported by the results of our decomposition experiment showing that buried Spartina alterniflora litter becomes isotopically more negative over time, although litter that was degraded on the surface of the marsh was not significantly different in isotopic composition than fresh litter (Table 3). Apparently aerobic and anaerobic processes differ in their effect on isotopic fractionation. Possibly these differences may also be related to whether the decomposing organisms are solely bacterial or an association of bacteria and fungi, since fungi would not be expected to be active in the anoxic marsh subsurface. Similarly, Schwinghamer et al. (1983) observed that 'aged' detritus was more negative than 'fresh' by 4 to $7 \%$. Spiker \& Hatcher (1984) report an overall decrease of at least $4 \%$ during early diagenesis of decomposing algae in marine sediment.

The second process that influences the isotopic composition of the sediment involves input of organic matter from other sources - such as bacteria, algae, the $\mathrm{C}-3$ plant Juncus roemerianus, and other plants - all of which have a wide range of stable carbon isotope ratios (Table 1). For example, in the salt marsh at Sapelo Island, Georgia, SOM from a mixed stand of Spartina alterniflora and $J$. roemerianus was isotopically intermediate $(-22.8 \%$ w $)$ when compared to (a) $\delta^{13} \mathrm{C}$ values of floral end members $(-12.5$ and $-26.0 \%$, respectively) and (b) SOM sampled in individual macrophyte stands $(-19.4$ and $-24.0 \%$, respectively) (Hughes \& Sherr 1983). The $\delta^{13} \mathrm{C}$ of the SOM in North Inlet may thus be the combination of the weighted contributions of the plant sources represented in the marsh system.

The relative proportions of these different carbon inputs may change with location in the marsh. For example, $\delta^{13} \mathrm{C}$ values of SOM become more positive with increasing distance from the marsh creek (Fig. 2), i.e. richer in ${ }^{13} \mathrm{C}$ and more characteristic of the Spartina alterniflora contribution in the sediment. Haines (1976) attributed similar results for a Georgia Spartina salt marsh to the proportional increase of $S$. alterniflora litter in the soil. Hughes \& Sherr (1983) found that when creekbank sediment $\delta^{13} \mathrm{C}$ values were compared to those of the creekbed in the same location, the creekbank more closely reflected the $\delta^{13} \mathrm{C}$ of the major macrophyte present, $S$. alterniflora. Whelan et al. (1986) analyzed the lignin pyrolysis products of Georgia salt marsh SOM and confirmed these results.

In creekbank sites examined in the North Inlet marsh, SOM had the most negative $\delta^{13} \mathrm{C}$ values compared to any other site. Potential sources of more ${ }^{13} \mathrm{C}$ depleted carbon at this site could be benthic algae, and sedimentation of phytoplankton and other allochthonous carbon from tidal creek waters. Rates of sedimentation of particulate matter are significantly higher in the tall Spartina alterniflora zone compared to the short $S$. 
alterniflora zone (Letzsch \& Frey 1980). Where the rate of sedimentation is high, input of phytoplankton and allochthonous carbon (possibly terrestrial in origin) are more significant, which dilutes $S$, alterniflora input to SOM. Phytoplankton and fine particulate carbon are much more depleted in ${ }^{13} \mathrm{C}$ than $S$. alterniflora. Terrestrial sources of carbon are also possible because organic carbon enters the marsh in the form of dissolved and colloidal material adhering to silt and clay particles (Schwinghamer et al. 1983). Wolaver et al. (1986) have concluded that the source of dissolved organic carbon in tidal creeks at North Inlet is largely from runoff from surrounding freshwater swamps during periods of high rainfall. Thus, creekbanks with their high sedimentation rates could be sinks for terrestrial carbon.

Bacterial carbon can probably be discounted as a major component of SOM because of the large quantity of bacterial biomass that would be required to decrease the $\delta^{13} \mathrm{C}$ of SOM to the observed range of -17 to $-21 \%$ from the $-13.5 \%$ characteristic of live Spartina alterniflora. If $\delta^{13} \mathrm{C}$ of SOM in the North Inlet marsh was strictly a function of the relative amounts of bacterial and $S$. alterniflora carbon, then the organic carbon in SOM would need to be composed almost entirely of bacteria. Furthermore, the bacteria would most likely have to derive its nutrition from a source other than $S$. alterniflora, since heterotrophic bacteria apparently do not differ greatly in isotopic composition from that of their carbon source (Fry \& Sherr 1984, Blair et al. 1985) Schwinghamer ct al. (1983) reported that bacterial biomass contributed $1.3 \%$ to the total sedimentary carbon. Marinucci et al. (1983) found a total microbial carbon content of $2.6 \%$ of total carbon in aerobically degraded $S$. alterniflora litter. Therefore, it is unlikely that such a small standing stock of bacterial carbon per se could influence the isotopic composition of SOM.

To help discern the sources of SOM, an experiment based on the sedimentary size fraction concept of Schwinghamer et al. (1983) was performed. C/N ratios were determined to rule out the possibility that fine fractions may contain significant amounts of lignocellulose, because nitrogen is a minor constituent of polysaccharides (Wilson et al. 1986). Macro-organic matter has more positive $\delta^{13} \mathrm{C}$ values and higher $\mathrm{C} / \mathrm{N}$ ratios, while fine particulates have more negative $\delta^{13} \mathrm{C}$ values and lower $\mathrm{C} / \mathrm{N}$ ratios (Fig. 4). Bacteria and thoroughly decomposed SOM have similar $\delta^{13} \mathrm{C}$ and C/ $\mathrm{N}$ values that are quite different from fresh Spartina alterniflora litter (Fig. 4). Partially decomposed macroorganic matter from 29 to $34 \mathrm{~cm}$ sediment depth was intermediate in composition.

Microorganisms typically have low $\mathrm{C} / \mathrm{N}$ ratios ranging from 3:1 to 10:1 (Greenwood 1968, Hunter 1976,

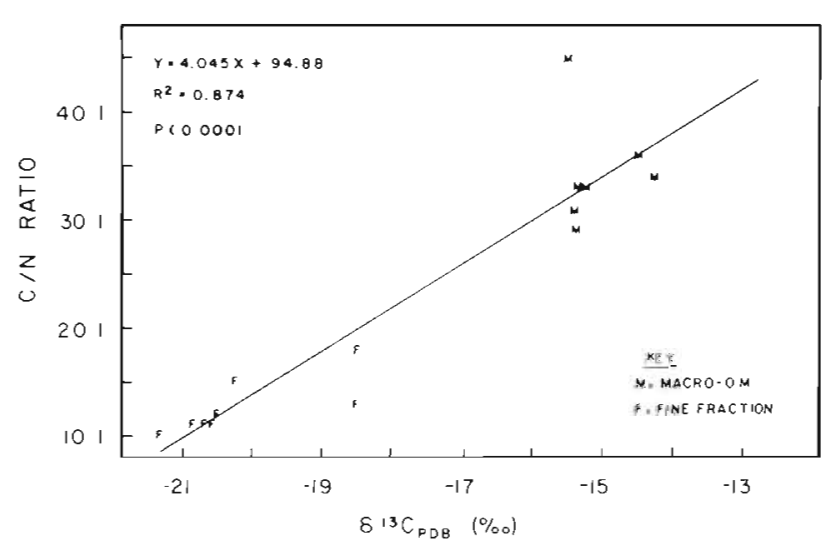

Fig. 4. Plot of $\mathrm{C} / \mathrm{N}$ ratios vs $\delta^{13} \mathrm{C}$ values for sediment samples collected from all sites at a depth of 29 to $34 \mathrm{~cm}$ on April 22, 1984. Samples were sieved through a $710 \mu \mathrm{m}$ screen into 2 fractions: (1) Macro-organic matter (M) - material larger than $710 \mu \mathrm{m}$; (2) fine sediment $(F)-$ less than $710 \mu \mathrm{m}$. Line: least squares fit to data

Philp \& Calvin 1976), while fresh Spartina alterniflora litter has a relatively high $\mathrm{C} / \mathrm{N}$ ratio, approaching $40: 1$ (Russel-Hunter 1970, Marinucci 1982). Apparently, the $\mathrm{C} / \mathrm{N}$ ratio of decomposing $S$. alterniflora litter changes in such a way as to resemble bacterial biomass. However, laboratory studies by Rice \& Tenore (1981) showed that an increase in the bacterial biomass alone cannot account for decreasing $\mathrm{C} / \mathrm{N}$ ratios in decomposing $S$. alterniflora litter. Wilson et al. (1986) reported an increase in the nitrogen content of $S$. alterniflora foliowing 2 yr of in situ decomposition, which they attributed to the retention and concentration of refractory nitrogen-enriched non-protein complexes of organic matter from the original litter. Less than $20 \%$ of the nitrogen was attributed to microbial biomass. It is intriguing that the diagenesis of SOM should lead to material that resembles the $\mathrm{C} / \mathrm{N}$ and carbon isotope ratios of bacteria.

The community of microbial decomposers may not be exclusively bacterial in composition, although bacteria are recognised to be the major decomposers of organic matter in anaerobic marine sediments (Fenchel \& Blackburn 1979). In contrast, fungi are thought to be important decomposers of standing dead $S$. alterniflora litter (Newell \& Hicks 1982) under aerobic conditions. However, bacteria appear to be the main decomposers of the lignocellulose of $S$. alterniflora, which makes up the bulk of the plant (Benner et al. $1984 \mathrm{a}, 1986)$. The major part of lignin degradation occurs under near-surface conditions mediated by aerobic bacteria (Benner et al. 1984b); anaerobic bacteria contribute very little to this process (Valiela et al. 1984). Although the community of microbial decomposers is the driving force of early organic diagenesis, little is known about the isotopic composition of these 
different groups of microbes and the role they may play in determining the $\delta^{13} \mathrm{C}$ value of SOM.

Bioturbation also could influence the depth profile of carbon isotope values and organic content along a transect. Fiddler crabs and other infauna mix surface sediment containing larger quantities of organic matter with deeper sediment containing lower quantities. In doing so, surface detrital Spartina alterniflora is mixed with other sources of organic carbon which are generally more depleted in ${ }^{13} \mathrm{C}$ than $S$. alterniflora. Homogenization of marsh soil is most intense near the creekbank, and decreases inland. Bioturbated sediment has been observed to a depth greater than $30 \mathrm{~cm}$ on the creekbank and in the tall $S$. alterniflora zone, to depths of 4 to $5 \mathrm{~cm}$ in the medium $S$. alterniflora zone, and to depths of less than $2 \mathrm{~cm}$ in the short $S$. alterniflora zone (Sharma et al. in press). Thus, the effects of bioturbation are not equal in all parts of the marsh.

The $\delta^{13} \mathrm{C}$ values and carbon content of SOM (Fig. 3) from a short Spartina alterniflora site have been least altered by the processes of bioturbation and sedimentation compared to the sites closer to the tidal creek. As Fig. 3 shows, where bioturbation can be discounted, the correlations between stable carbon isotope ratios, organic carbon content, and sample depth become more significant. This supports the hypothesis that isotopically lighter carbon is preserved during SOM diagenesis.

There are at least 3 important processes that appear to shape the isotopic compositions of SOM in salt marsh sediments. Firstly, selective preservation of refractory carbon compounds with an isotopic signature, such as lignin, that is lighter than the original whole tissue. As lignin is concentrated in gradually degrading SOM, the isotopic ratio of the remaining organic matter approaches that of lignin (Table 3). Diagenesis may continue in this fashion for years. Secondly, the extent of bioturbation differs between the different zones of Spartina alterniflora growth forms in the salt marsh (Sharma et al. in press, Gardner et al. in press), which tends to homogenize the organic carbon content and the carbon isotope ratios between surface and subsurface. Lastly, sedimentation also differs between these zones. The sedimentation process could result in the input of isotopically light carbon from planktonic or terrestrial sources. Benthic algae, which are slightly isotopically positive compared to the above organic materials (Table 1), are also a source of SOM and could influence the isotopic composition of marsh sediments.

Our results indicate that the processes affecting accumulation and diagenesis of organic matter in marsh sediments are complex and that the carbon sources probably cannot be identified by single element isotope analyses. Additional laboratory experi- ments that investigate the relation between stable isotopes and (a) bacterial and fungal decomposition and (b) biochemical components of Spartina alterniflora are needed to fully understand organic matter diagenesis in sediments.

Acknowledgements. We thank J. Melillo and E. Firth for providing samples of Spartina alterniflora lignin and degraded $S$. alterniflora, respectively. We are grateful to the Stable Isotope Laboratory of the University of South Carolina for use of the mass spectrometer and to the Belle W. Baruch Institute for salt marsh research sites. This research was supported by the Marine Science Program and the Belle W. Baruch Institute of the University of South Carolina, and grant BSR 83-17407 from the National Science Foundation to J. T Morris. This is contribution \# 642 of the Baruch Institute.

\section{LITERATURE CITED}

Bender, M. M. (1971). Variations in the ${ }^{i 3} \mathrm{C} /{ }^{i 2} \mathrm{C}$ ratios of plants in relation to the pathway of photosynthesis carbon dioxide fixation. Phytochemistry 10: 1039-1244

Benner, R., Maccubbin, A. E., Hodson, R. E. (1984a). Preparation, characterization, and microbial degradation of specifically radiolabeled $1{ }^{14} \mathrm{C}$ Lignocelluloses from marine and freshwater macrophytes. Appl. environ. Microbiol. 47. 381-389

Benner, R., Moran, M. A., Hodson, R. E. (1985). Effects of $\mathrm{pH}$ and plant source on lignocellulose biodegradation rates in two wetland ecosystems, the Okefenokee Swamp and a Georgia salt marsh. Limnol. Oceanogr. 30: 489-499

Benner, R., Moran, M. A., Hodson, R. E. (1986). Biogeochemical cycling of lignocellulosic carbon in marine and freshwater systems: relative contributions of procaryotes and eucaryotes. Limnol. Oceanogr. 31: 89-100

Benner, R., Newell, S. Y., Maccubbin, A. E., Hodson, R. E. (1984b). Relative contributions of bacteria and fungi to rates of degradation of lignocellulosic detritus in saltmarsh sediments. Appl. environ. Microbiol. 48: 36-40

Blair, N., Leu, A., Muñoz, E., Olsen, J., Kwong, E., Des Marias, D. (1985). Carbon isotopic fractionation in heterotrophic microbial metabolism. Appl. environ. Microbiol. 50: 996-1001

Buchanan, D., Corcoran, B. (1959). Sealed tube combustions for the determination of ${ }^{14} \mathrm{C}$ and total carbon. Analyt. Chem. 31: 1635-1638

Coplen, T. B., Kendall, C., Hopple, J. (1983). Comparison of stable isotope reference samples. Nature, Lond. 302: 236-238

Craig, H. (1957). Isotopic standards for carbon and oxygen and correction factors for mass-spectrometric analysis of carbon dioxide. Geochim. cosmochim. Acta 12: 133-149

Degens, E. T., Behrendt, M., Gotthardt, B., Reppmann, E. (1968). Metabolic fractionation of carbon isotopes in marine plankton - II. Data on samples collected off the coasts of Peru and Ecuador. Deep Sea Res. 15: 11-20

DeNiro, M. J., Epstein, S. (1978). Influence of diet on the distribution of carbon isotopes in animals. Geochim. cosmochim. Acta 42: 495-506

Ember, L. M. (1985). Sources of sedimentary organic matter in Spartina-dominated salt marshes. Master's thesis, University of South Carolina, Columbia. S. C.

Fenchel, T., Blackburn, T. H. (1979). Bacteria and mineral cycling. Academic Press, London 
Fry, B. (1984). ${ }^{13} \mathrm{C} /{ }^{12} \mathrm{C}$ ratios and the trophic importance of algae in Florida Syringodium filiforme seagrass meadows Mar. Biol. 79: 11-19

Fry, B., Scanlan, R. S., Parker, P. L. (1977). Stable carbon isotope evidence for two sources of organic matter in coastal sediments: seagrasses and plankton. Geochim. cosmochim. Acta 41: 1875-1877

Fry, B., Sherr, E. B. (1984). ${ }^{13}$ C measurements as indicators of carbon flow in marine and freshwater ecosystems. Contr. mar. Sci. 27: 13-47

Gardner, L. R., Sharma, P., Moore, W. S. (in press). A regeneration model for the effect of bioturbation by fiddler crabs on ${ }^{219} \mathrm{~Pb}$ profiles in salt marsh sediments. J. environ. Rad. Activ.

Gearing, J. N., Gearing, P. J., Rudnick, D. T., Requejo, A. J., Hutchins, M. J. (1984). Isotopic variability of organic carbon in a phytoplankton-based temperate estuary. Geochim. cosmochim. Acta 48: 1089-1098

Goering, H. K., Van Soest, P. J. (1970). Forage fiber analysis. Agricultural Handbook No. 379. Agricultural Research Service, USDA, Wash.

Greenwood, D. J. (1968). Measurement of microbial metabolism in soil. In: Gray, T. R. G., Parkinson, D. (ed.) The ecology of soil bacteria. Liverpool University Press, Liverpool, UK

Hackney, C. T., Haines, E. B. (1980). Stable carbon isotope composition of fauna and organic matter collected in a Mississippi estuary. Estuar. coast. mar. Sci. 10: 703-708

Haines, E. B. (1976). Stable carbon isotope ratios in the biota soils, and tidal water of a Georgia salt marsh. Estuar. coast. mar. Sci. 4: 609-616

Haines, E. B. (1977). The origins of detritus in Georgia salt marsh estuaries. Oikos 29: 254-260

Haines, E. B., Hanson, R. B. (1979). Experimental degradation of detritus made from the salt marsh plants Spartina alterniflora Loisel., Salicornia virginica L., and Juncus roemerianus Schelle. J. exp. mar. Biol. Ecol. 40: 27-40

Haines, E. B., Montágue, C. L. (19979). Food sources of estuarine invertebrates analyzed using ${ }^{13} \mathrm{C} /{ }^{12} \mathrm{C}$ ratios. Ecology 60: 48-56

Hatcher, P. G., Maciel, G. E., Dennis, L. W. (1981). Aliphatic structure of humic acids: a clue to their origin. Org. Geochem. 3: 43-48

Hatcher, P. G., Simoneit, B. R. T., Mackenzie, F. T., Neumann, A. C., Thorstenson, D. C., Gerchakov, S. M. (1982). Organic geochemistry and pore water chemistry of sediments from Mangrove Lake, Bermuda. Org. Geochem. 4: 93-112

Hatcher, P. G., Spiker, E. C., Szevereryi, N. M., Maciel, G. E. (1983). Selective preservation and origin of petroleumforming aquatic kerogen. Nature, Lond. 305: 498-501

Hodson, R. E., Christian, R. R., Maccubbin, A. E. (1984). Lignocellulose and lignin in the salt marsh grass Spartina alterniflora: initial concentrations and short-term, postdepositional changes in detrital matter. Mar. Biol. 81: 1-7

Howarth, R. W., Giblin, A. (1983). Sulfate reduction in the salt marshes at Sapelo Island, Georgia. Limnol. Oceanogr. 28 $70-82$

Howarth, R. W., Teal, J. M. (1979). Sulfate reduction in a New England salt marsh. Limnol. Oceanogr. 24: 999-1013

Hughes, E. H., Sherr, E. B. (1983). Subtidal food webs in a Georgia estuary: ${ }^{13} \mathrm{C}$ analysis. J. exp. mar. Biol. Ecol. 67: 227-242

Hunter, R. K. (1976). Changes in carbon and nitrogen content during decomposition of three macrophytes in freshwater and marine environments. Hydrobiologia 51: 119-128

Johnson, R. W., Calder, J. A. (1973). Early diagenesis of fatty acids and hydrocarbons in a salt marsh environment Geochim. cosmochim. Acta 37: 1943-1955

Kruczynski, W. L., Subrahmanyam, C. B., Drake, S. H. (1978) Studies on the plant community of a north Florida salt marsh. Part II. Nutritive value and decomposition. Bull. mar. Sci. 28: 707-715

Letzsch, W. S., Frey, R. W. (1980). Deposition and erosion in a Holocene salt marsh, Sapelo Island, Georgia. J. sedim. Petrol. 50: 529-542

Maccubbin, A. E., Hodson, R. E. (1980). Mineralization of detrital lignocelluloses by salt marsh sediment microflora. Appl. environ. Microbiol. 40: 735-740

Marinucci, A. C. (1982). Trophic importance of Spartina alterniflora production and decomposition to the marshecosystem. Biol. Conserv. 22: 35-58

Marinucci, A. C., Hobbie, J. E., Helfrich, J. V. K. (1983). Effect of litter nitrogen on decomposition and microbial biomass in Spartina alterniflora. Microb. Ecol. 9: 27-40

Morris, J. T., Lajtha, K. (1986). Decomposition and nutrient dynamics of litter from four species of freshwater emergent macrophytes. Hydrobiologia 131: 215-223

Morris, J. T., Whiting, G. J. (1986). Emission of gaseous carbon dioxide from salt-marsh sediments and its relation to other carbon losses. Estuaries 9: 9-19

Newell, S. Y., Hicks, R. E. (1982). Direct-count estimates of fungal and bacterial biovolume in dead leaves of smooth cordgrass (Spartina alterniflora Loisel.). Estuaries 5: $246-260$

Park, R., Epstein, S. (1960). Carbon isotope fractionation during photosynthesis. Geochim. cosmochim. Acta 21: $110-126$

Park, R., Epstein, S. (1961). Metabolic fractionation of ${ }^{13} \mathrm{C}$ and ${ }^{12} \mathrm{C}$ in plants. Pl. Physiol., Wash. 36: 133-138

Peterson, B. J., Howarth, R. W., Lipschultz, F., Ashendorf, D. (1980). Salt marsh detritus: an alternate interpretation of stable carbon isotope ratios and the fate of Spartina aiterniflora. Oikos 34: 173-177

Philp, R. P., Calvin, M. (1976). Possible origin for insoluble organic (kerogen) debris in sediment from insoluble cellwall materials of algae and bacteria. Nature, Lond. 262 134-136

Rice, D. L., Tenore, K. R. (1981). Dynamics of carbon and nitrogen during the decomposition of detritus derived from estuarine macrophytes. Estuar. coast. Shelf Sci. 13: 681-690

Rodelli, M. R., Gearing, J. N., Gearing, P. J., Marshall, N. Sasekumar, A. (1984). Stable isotope ratio as a tracer of mangrove carbon in Malaysian ecosystems. Oecologia (Berl.) 61: 326-333

Russell-Hunter, W. D. (1970). Aquatic production. MacMillan Co., New York

Schwinghamer, P., Tan, F. C., Gordon, D. C., Jr. (1983). Stable carbon isotope studies on the Pecks Cove mudflat ecosystem in the Cumberland Basin, Bay of Fundy. Can. J. Fish Aquat. Sci. 40 (Suppl. 1): 262-272

Sharma, P., Gardner, L. R., Bollinger, M. S., Moore, W. S. (in press). Sedimentation and bioturbation in a salt marsh as revealed by $\mathrm{Pb}-210, \mathrm{Cs}-137$ and $\mathrm{Be}-7$ studies. Limnol. Oceanogr.

Sirevag, R, Buchanan, B. B., Berry, J. A., Troughton, J. H (1977). Mechanisms of $\mathrm{CO}_{2}$ fixation in bacterial photosynthesis studied by the carbon isotope fractionation technique. Arch. Microbiol. 112: 35-38

Smith, B. N., Epstein, S. (1971). Two categories of ${ }^{13} \mathrm{C} /{ }^{12} \mathrm{C}$ ratios for higher plants. Pl. Physiol., Wash. 47: 380-384

Spies, R. B., DesMarias, D. J. (1983). Natural isotope study of 
trophic enrichment of marine benthic communities by petroleum seepage. Mar. Biol. 73: 67-71

Spiker, E. C., Hatcher, P. G. (1984). Carbon isotope fractionation of sapropelic organic matter during early diagenesis. Org. Geochem. 5: 283-290

Stephenson, R. L., Lyon, G. L. (1982). Carbon-13 depletion in an estuarine bivalve: detection of marine and terrestrial food sources. Oecologia (Berl.) 55: 110-113

Sternberg, L. O., DeNiro, M. J., Johnson, H. B. (1984). Isotope ratios of cellulose from plants having different photosynthetic pathways. Pl. Physiol., Wash. 74: 557-561

Thayer, G. W., Parker, P. L., LaCroix, M. W., Fry, B. (1978). The stable carbon isotope ratio of some components of an eelgrass, Zostera marina, bed. Oecologia (Berl.) 35: 1-12

Valiela, I., Wilson, J., Buchsbaum, R., Rietsma, C., Bryant, D., Foreman, K., Teal, J. (1984). Importance of chemical composition of salt marsh litter on decay rates and feeding by detritivores. Bull. mar. Sci. 35: 261-269
Whelan, J. K., Tarafa, M. E., Sherr, E. B. (1986). Phenolic and lignin pyrolysis products of plants, seston, and sediment in a Georgia estuary. In: Shon, M. L. (ed.) Organic Marine Geochemistry. American Chemical Society, Washington, D.C. ACS Symp. Ser. 305: 62-75

White, D. A., Weiss, T. E., Trapani, J. M., Thien, L. B. (1978). Productivity and decomposition of the dominant salt marsh plants in Louisiana. Ecology 59: 751-759

Wilson, J. O., Buchsbaum, R., Valiela, I., Swain, T. (1986). Decomposition in salt marsh ecosystems: phenolic dynamics during decay of litter of Spartina alterniflora. Mar. Ecol. Prog. Ser. 29: 177-187

Wolaver, T. G., Hutchinson, S., Marozas, M. (1986). Dissolved and particulate carbon in the North Inlet Estuary, South Carolina: what controls their concentration? Estuaries 9: 31-38

This article was presented by Dr. S. Y. Newell; it was accepted for printing on November 10, 1986 